\title{
TRANSLATION AND ADAPTATION OF THE ACTION CONTROL SCALE AIMED AT NURSING CARE ${ }^{1}$
}

\author{
Elen Martins da Silva Castelo Branco ${ }^{2}$, Maurício de Abreu Pinto Peixoto ${ }^{3}$, Neide Aparecida Titonelli Alvim ${ }^{4}$
}

\footnotetext{
${ }^{1}$ Paper taken from the dissertation - The control of nursing students' actions in the implementation of preventive care for pressure ulcer, presented to the Graduate Program at Anna Nery School of Nursing (EEAN), Universidade Federal do Rio de Janeiro (UFRJ), in 2007.

2 Ph.D. in Nursing. Adjunct Professor at EEAN/UFRJ. Rio de Janeiro, Rio de Janeiro, Brazil. E-mail: elencastelobranco@yahoo. com.br

${ }^{3}$ Ph.D. in Medicine. Adjunct Professor, Educational Technology for Health Group at UFRJ. Rio de Janeiro, Rio de Janeiro, Brazil. E-mail: mpeixoto@nutes.ufrj.br

${ }^{4}$ Ph.D. in Nursing. Associate Professor at EEAN/UFRJ. Research productivity grantee, CNPq. Rio de Janeiro, Rio de Janeiro, Brazil. E-mail: titonelli@globo.com
}

\begin{abstract}
The study aimed to describe the of translation and adaptation phases of the questionnaire HAKEMP 90 to the Brazilian version. Derived from the Action Control Theory, the questionnaire consists of 36 items that identify the orientation towards action or state. The Spanish version was translated into Portuguese, back-translated into Spanish, reassessed by bilingual translators and tested in five nursing students. In the Brazilian version, the questionnaire kept the original format and nine items underwent replacement of terms for semantic equivalence. The fundamental concepts to investigate the action or state were kept in all stages. The cross-cultural adaptation to Portuguese language resulted in an appropriate tool, with understanding and agreement between the items. The adapted questionnaire represented a valuable resource for the student's success as a diagnostic tool, by enabling the early detection of risk factors for poor performance in specific situations.
\end{abstract}

DESCRIPTORS: Translation. Adaptation. Learning. Nursing.

\section{TRADUÇÃO E ADAPTAÇÃO DA ESCALA DO CONTROLE DA AÇÃO VISANDO AO CUIDADO DE ENFERMAGEM}

RESUMO: O artigo objetivou descrever as fases da tradução e adaptação do questionário HAKEMP 90 para a versão brasileira. Derivado da Teoria do Controle da Ação, o questionário consiste em 36 itens que identificam a orientação para ação ou estado. No estudo, a versão espanhola foi traduzida para o português, retraduzida para o espanhol, reavaliada por tradutores bilíngues e testada com cinco graduandos de enfermagem. Na versão brasileira, o questionário manteve o formato original e nove itens sofreram substituição de termos para equivalência semântica. Os conceitos fundamentais para a investigação da ação ou estado foram mantidos em todas as etapas. A adaptação transcultural resultou em um instrumento adequado à língua portuguesa, apresentando compreensão e concordância entre os itens. O questionário adaptado configurou um recurso valioso para o êxito do estudante enquanto ferramenta diagnóstica, por viabilizar a descoberta precoce do risco para o desempenho insatisfatório em situações específicas.

DESCRITORES: Tradução. Adaptação. Aprendizagem. Enfermagem.

\section{TRADUCCIÓN Y ADAPTACIÓN DE LA ESCALA DEL CONTROL DE LA ACCIÓN CON VISTAS A LA ATENCIÓN DE ENFERMERÍA}

\begin{abstract}
RESUMEN: El propósito del artículo es describir las fases de traducción y adaptación del cuestionario HAKEMP 90 a la versión brasileña. Derivado de la Teoría del Control de la Acción, el cuestionario contiene 36 ítems que identifican la orientación a acción o estado. La versión española fue traducida al portugués, traducida al español, revisada por traductor bilingüe y probado en cinco estudiantes de enfermería. En la versión brasileña, el cuestionario mantuvo el formato original y nueve ítems sufrieron sustitución de términos para equivalencia semántica. Los conceptos fundamentales para la orientación a acción o estado se mantuvieron en todas las etapas. La adaptación resultó en un instrumento adecuado para el portugués, con entendimiento y acuerdo entre los artículos. El cuestionario adaptado establece un recurso valioso para el éxito del estudiante como una herramienta de diagnóstico, al permitir la detección de factores de riesgo de mal desempeño en situaciones específicas.
\end{abstract}

DESCRIPTORES: Traducción. Adaptación. Aprendizaje. Enfermería. 


\section{INTRODUCTION}

In this paper, the translation and adaptation of the HAKEMP 90 questionnaire to the Brazilian version are described. The HAKEMP 90 questionnaire derives from the Action Control Theory (ACT), which rests on two basic proposals. The first refers to desires, expectations, values and other motivational trends as determinant factors of action. The second is related to volitional processes, internal and external distractions as factors that interfere in the relation between intention and concrete action.

Through the application of this questionnaire, the orientation towards action or state can be identified, contributing to the recommendation of self-regulation strategies to accomplish learning tasks. It also describes the maintenance of the focus on the accomplishment of specific tasks in the presence of internal distractions, such as academic failure, and external distractions like environmental stimuli. ${ }^{1}$

It should be highlighted that the daily activities, personal and situational characteristics of the hospital environment cause deviations in the nurses' attention, which can affect the quality of care delivered to patients and their relatives. ${ }^{2}$

Among other factors, it is relevant to consider that a distraction can cause a decrease in voluntary attention. Distractions delay or impede the action and their presence, to a greater or lesser extent, interferes in the concentration and ends up distancing or abolishing the achievement of the initial objective. Based on the above, in view of the factors that cause distractions, it is relevant to seek an integrative approach that contributes to conscious and active learning.

Investigating the action control is essential for the autonomy of learning, as the actions are assessed and adapted, permitting greater attention and concentration. Self-regulation is part of that perspective, conceived as people's capacity to drive their own conduct by reflecting and operating individual and contextual characteristics. ${ }^{3}$

Self-regulated students demonstrate greater constancy in the planning, implementation and execution of the action, as the self-reflections on earlier learning situations affect the previous phase of subsequent learning situations. ${ }^{4}$ In addition, they evidence the adaptation and modification of the adopted strategies, when obstacles emerge between the preparation and practice to achieve the objectives, at the end. The management of distractions is more effective, the objectives are concrete and there is coherence in the planning of the actions and in the way of acting. In addition, the output and achievement of the targets become more effective, as greater capacity is perceived to override small failures. ${ }^{5-6}$ Self-regulation incorporates different processes that monitor and control the behavior. These processes, including attention, motivation, emotion and control of the action, are useful for the use of cognitive strategies. ${ }^{\text {? }}$

In summary, the ACT permits classifying the students as oriented towards action or state, according to peculiar motivational, volitional and intentional characteristics. Action-oriented people are actively involved in the achievement of objectives, maintain optimistic attitudes towards life and show high levels of emotional wellbeing, in contrast with state-oriented people. ${ }^{1}$

The orientation towards action demonstrates greater capacity to concentrate in view of distractions, due to irrelevant thoughts or events, whether in the present or past. In that sense, the trend goes towards change, which facilitates the integration with the negative experiences and the achievement of targets. In the orientation towards state, people demonstrated the above-described regulations to a lesser extent. They present an excessive focus on negative past experiences and tend towards immobility, that is, there is a lack of individual skills to regulate the emotion and the attitudes needed to conclude the intended actions. ${ }^{8}$

In terms of opposite parameters, the orientation towards state shows three components that correspond to the orientation towards action: concern, hesitation and volatility (instability). ${ }^{9}$ State-oriented people evidence negative and longlasting emotional conditions after going through unpleasant situations. In this type of orientation, it is highlighted that people are more concerned with other people's opinion and look for the means to impress them. The trend to give up the action of task in response to academic failure reveals a low level of persistence. State-oriented students remain imprisoned in past events instead of concentrating on future performance. The distractions easily cause attention slips and reduce the cognitive resources that contribute to the achievement of the targets. ${ }^{6}$

In the academic sphere, the HAKEMP 90 is a valid instrument, developed in the 1980's by Julius Kuhl, a psychologist and researcher from the University of Osnabrück, Germany. The tool joints attitudes expected in both orientations, keeping in 
mind that the road between will and intention is filled with obstacles. ${ }^{10}$ In this tool, the premises of the ACT further the understanding of the active process that transforms intentions into actions. As a result of its application, nursing students' selfdetermination regarding thought and action in their own learning becomes even more valuable. In addition, it permits the individual or collective study of the relation between the students' expectations and the course of their actions. ${ }^{11-12}$

Based on the above, the objective is to describe the translation and adaptation of the HAKEMP 90 questionnaire to Portuguese. Therefore, the semantic equivalence and cross-cultural adaptation of the tool should be appropriate for application to nursing students in Brazil.

\section{METHOD}

Translation and cross-cultural adaptation is a methodological process concerned with tools for use in situations that differ from the situations they were developed for. Assessing the semantic equivalence involves the capacity to transfer meaning from the concepts in the original instrument to the translated version, exercising a similar effect on the respondents in the two cultures. ${ }^{13}$

For the translation, back-translation and cross-cultural adaptation of the HAKEMP 90 questionnaire, undertaken in July, August and September 2007, the following phases were undertaken: forwarding of the Spanish version to the independent bilingual translators, elaboration of the preliminary version in Portuguese, back translation of the preliminary version to Spanish, comparison between original version and translated version for semantic, idiomatic and conceptual analysis, application of the pre-test and final formatting of the questionnaire. ${ }^{14-15}$

The Brazilian version of the questionnaire was submitted to a pilot test, applied in five nursing students from a federal higher education institution, being four female participants and one male, between 19 and 23 years of age. As inclusion criteria, the students should be taking the fifth term, engaged in activities in the hospital context and should accept to participate in the stud by signing an Informed Consent Form. The participants were informed that the pilot test would not influence the assessment of the curricular activities.

Approval for the study was obtained from the Institutional Review Board of the University Hospital Clementino Fraga Filho, under research protocol 097/06. It should be highlighted that the participants in the pilot test were not included in the data collection for the dissertation, as they were already in the sixth term at that time.

\section{RESULTS}

\section{Description of the phases}

\section{The choice of the tool}

The HAKEMP 90 is available in German, English and Spanish. It contains 36 items, divided in three subscales that investigate the action control in the accomplishment of tasks, in planning and deciding on the action to execute an activity. There are two alternative responses to each item: one indicates the orientation towards action and the other towards state. The questions are appropriate for application in adolescents (as from the age of 12 years) as well as adults. ${ }^{16}$

The first subscale contains the items that refer to the orientation towards action/state after failure (OAF). The second contains the items for action/state in planning and deciding on the action $(\mathrm{OAP})$ and the third refers to the orientation towards action/state in successful activities or intrinsic motivation (OAA).

The use of the OAF scale is particularly indicated in situations focused on the deficient implementation observed in students in view of the experience of failure. Hence, it permits predicting that, in cases of orientation towards stage, there is less control over negative thoughts and attitudes in view of recent failure, and the reduced persistence and effort interfere in the execution of the new task. ${ }^{16-17}$

The OAP scale permits detecting the coherence between the intention and the concrete action. Coherent behavior is predominant among actionoriented individuals. The OAA scale indicates the subject's degree of intentional development to accomplish the task. This measure can be interpreted as the intrinsic motivational focus in the activity itself, in contrast with the activity that is essentially centered on the achievement of the target. ${ }^{16}$

For the sake of the study, the choice of the Spanish version is justified as it is a Latin language close to Portuguese. The assessment process of the semantic equivalence to Portuguese used the translation of the original tool to the target language, the back translation to Spanish and the cross-cultural adaptation. One of the members of 
the tool author's research theme intermediated the authorization to use the HAKEMP 90, who readily sent the English and Spanish version by e-mail and the instructions for their interpretation.

\section{The translation to the target language and the back translation to Spanish}

The two translators received a script with the details of their participation, a copy of the study and the list of the 36 items in Spanish to register the translation, mainly regarding the clarity of the language, pertinence and consistency of the statements, in relation to the objectives of the phase and of the study in general.

The Spanish version was forwarded to the translator whose mother tongue is Portuguese and, thus, a new version of the HAKEMP 90 was created, hereinafter called H1. Next, the Portuguese version (H1) was forwarded to the other translator to elaborate the back translation from the target language to the original in Spanish, which was called H2.
Subsequently, a meeting was scheduled with the translators to compare $\mathrm{H} 1$ and $\mathrm{H} 2$, so as to identify any discrepancies and provide for meanings that corresponded to the Brazilian context. Thus, the two translators adapted the semantic equivalence of nine items for the sake of greater conformity with the original tool. The preliminary version was prepared for the pilot test, respecting the arrangement of the items and the author's recommendations.

In the translation, words, expressions and verbal conjugations were adapted to enhance the subject's understanding. In all items, words were suppressed and replaced, like in item 1 for example, "Quando perco algo valioso para mim e não posso encontrar em nenhum lugar", the expression "para mim" was removed, and in item 17, "Normalmente, consigo fazê-lo de imediato" was replaced by "fazê-lo imediatamente". Figure 1 shows the nine items that were modified after the translation, back translation and comparison between versions $\mathrm{H} 1$ and $\mathrm{H} 2$.

\section{Figure 1 - Comparison between original items and items modified by the translators}

\begin{tabular}{|c|}
\hline \\
\hline $\begin{array}{l}\text { otra cosa. } \\
\text { s tarde. }\end{array}$ \\
\hline $\begin{array}{l}\text { que terminar algo pronto: } \\
\text { go que obligarme para empezar. } \\
\text { erme a hacerlo y terminarlo. }\end{array}$ \\
\hline $\begin{array}{l}\text { Si he trabajado durante semanas en un proyecto y } \\
\text { espués todo sale mal: } \\
\text { Necesito mucho tiempo para adaptarme a eso. }\end{array}$ \\
\hline
\end{tabular}
10. Si acabara de comprar un aparato nuevo (por ejemplo, una radio) y por accidente se cae al suelo y no tiene arreglo:
a) Intentaría superarlo pronto.
b) Necesitaría mucho tiempo para superarlo.

17. Cuando tengo que hacer trabajo en casa:
a) A menudo me cuesta ponerme a trabajar.
b) Normalmente consigo hacerlo de inmediato.

23. Cuando hay dos cosas que de verdad quiero hacer pero no puedo hacer las dos:
a) Enseguida empiezo a hacer una cosa y me olvido de
la otra que no he podido hacer.
b) Me resulta difícil quitarme de la cabeza la otra cosa que no he podido hacer.

30. Cuando resulta que soy mucho mejor en un juego que los demás:
a) Normalmente me apetece hacer otra cosa.
b) Tengo claro que quiero seguir jugando.

Modified item
1. Quando perco algo valioso e não consigo encontrar em
lugar nenhum:
a) É difícil me concentrar em outra coisa.
b) Retomo facilmente a concentração.
2. Quando tenho que terminar algo rapidamente:
a) Muitas vezes tenho que me obrigar a começar.
b) É fácil, para mim, começar e terminar.
4. Se tudo sai errado após trabalhar durante semanas em
um projeto:
a) Preciso de muito tempo para me adaptar à situação.
b) Isso me incomoda um pouco e depois não penso mais.

10. Se tivesse acabado de comprar um aparelho novo (por exemplo, um rádio) e, por acidente, ele caísse no chão e não tivesse conserto:

a) Tentaria superar rapidamente.

b) Precisaria de muito tempo para superar.

17. Quando tenho que fazer um trabalho em casa:

a) Às vezes, demoro a iniciá-lo.

b) Normalmente, consigo fazê-lo imediatamente.

23. Quando existem duas coisas que realmente quero fazer, mas não posso fazer ambas:

a) Começo a fazer uma coisa e me esqueço da outra coisa que não pude fazer.

b) É difícil esquecer da outra coisa que não pude fazer.

30. Quando acontece de eu ser muito melhor em um jogo do que os outros:

a) Normalmente, tenho vontade de fazer outra coisa.

b) É claro que quero continuar jogando. 
33. Cuando leo algo que me resulta interesante:

a) A veces quiero dejar el artículo y hacer otra cosa.

b) Me siento y leo el artículo durante mucho tiempo.

36. Cuando intento aprender algo nuevo que me interesa:

a) Me dedico a eso durante mucho tiempo.

b) Suelo necesitar una pausa para hacer otra cosa durante un rato.

\section{Pilot test of the tool}

The students received the preliminary version of the tool and the orientations regarding completion and the degree of difficulty to understand the items. The objective of the phase was to check the understanding of the tool and find support to consider the Portuguese version as ready for use.

In this phase, the translation was almost fully accepted. After reading and analyzing the tool, the
33. Quando leio um artigo interessante:

a) Às vezes, quero deixar o artigo e fazer outra coisa.

b) Sento e leio o artigo durante muito tempo.

36. Quando pretendo aprender algo novo que me interessa:

a) Dedico-me a isso durante muito tempo.

b) Necessito de pequenas pausas para fazer outra coisa, durante um tempo.

\section{Figure 2 - Comparison between translated items and items modified according to the pilot test}

\begin{tabular}{|c|c|}
\hline Item in Portuguese & Modified item \\
\hline $\begin{array}{l}\text { 5. Quando estou aborrecido porque não tenho nada de } \\
\text { concreto para fazer: } \\
\text { a) Custa-me decidir o que deveria fazer. } \\
\text { b) Encontro rapidamente o que fazer. }\end{array}$ & $\begin{array}{l}\text { 5. Quando estou aborrecido porque não tenho nada c } \\
\text { concreto para fazer: } \\
\text { a) Demoro a decidir o que deveria fazer. } \\
\text { b) Encontro rapidamente o que fazer. }\end{array}$ \\
\hline $\begin{array}{l}\text { 14. Quando tenho que decidir o que deveria fazer se de } \\
\text { forma inesperada tiver um tempo livre: } \\
\text { a) Levo muito tempo para decidir o que fazer neste tempo } \\
\text { livre. } \\
\text { b) Normalmente consigo decidir-me por algo que fazer } \\
\text { sem ter que pensar muito. }\end{array}$ & $\begin{array}{l}\text { 14. Quando tenho que decidir o que deveria fazer ao ter, } \\
\text { de forma inesperada, um tempo livre: } \\
\text { a) Levo muito tempo para decidir o que fazer. } \\
\text { b) Normalmente, consigo decidir o que fazer, sem ter que } \\
\text { pensar muito. }\end{array}$ \\
\hline $\begin{array}{l}\text { 24. Quando estou ocupado, trabalhando em um projeto } \\
\text { interessante: } \\
\text { a) Necessito fazer paradas frequentes e trabalhar em out- } \\
\text { ros projetos. } \\
\text { b) Posso seguir trabalhando no mesmo projeto durante } \\
\text { muito tempo. }\end{array}$ & $\begin{array}{l}\text { 24. Quando estou ocupado trabalhando em um projeto } \\
\text { interessante: } \\
\text { a) Preciso fazer intervalos frequentes e trabalhar em out- } \\
\text { ros projetos. } \\
\text { b) Permaneço trabalhando no mesmo projeto durante } \\
\text { muito tempo. }\end{array}$ \\
\hline $\begin{array}{l}\text { par com algo que é } \\
\text { el: }\end{array}$ & $\begin{array}{l}\text { enho que me ocupar com algo que é impor- } \\
\text { mbém é desagradável: } \\
\text { livro imediatamente. }\end{array}$ \\
\hline $\begin{array}{l}\text { 36. Quando pretendo aprender algo novo que me inter- } \\
\text { essa: } \\
\text { a) Dedico-me a isso durante muito tempo. } \\
\text { b) Necessito de pequenas pausas para fazer outra coisa, }\end{array}$ & $\begin{array}{l}\text { sejo aprender algo novo e interessante: } \\
\text { isso durante muito tempo. } \\
\text { e pequenas pausas para fazer outra coisa, } \\
\text { mpo. }\end{array}$ \\
\hline
\end{tabular}

The suggestions were forwarded to the translators for further assessment and, thus, the writing of the Brazilian version was defined, which was then applied to 46 nursing students as the data collection instrument for the dissertation, having its sensitivity and specificity analyzed. ${ }^{11}$ participants in the pilot test suggested changes in five items $(5,14,24,26$ and 36). The changes needed for the sake of agreement on these items, involving the replacement of terms with the same meaning and changes in the order of the phrases, did not alter the essence of the attitudes to be investigated in the original version. Figure 2 displays the comparison between the original items and the items modified after the pilot test.

\section{(14.}

b) Levo um tempo para fazê-lo por obrigação.

36. Quando desejo aprender algo novo e interessante:

a) Dedico-me a isso durante muito tempo.

b) Necessito de pequenas pausas para fazer outra coisa, durante um tempo.

\section{Brazilian version of the action control scale - HAKEMP 90}

The adaptation process of the HAKEMP 90 was considered appropriate in all phases. In the Brazilian version, the scale was called "Escala do Controle da Ação". The original 36-item format was preserved and the three subscales remained 
mixed, respecting the original distribution of the Spanish version. In Figure 3, the OAS subscale corresponds, in the full Portuguese version, to items $1,4,7,10,13,16,19,22,25,28,31$ and 34 . The
OAP subscale consists of items $2,5,8,11,14,17$, 20, 23, 26, 29, 32 and 35 (Figure 4). Finally, Figure 5 displays the OAA subscale, which consists of items $3,6,9,12,15,18,21,24,27,30,33$ and $36 .{ }^{16}$

\section{Figure 3 - Orientation towards action after failure (OAF) versus concern}

1. Quando perco algo valioso e não consigo encontrar em lugar nenhum:

a) É difícil me concentrar em outra coisa.

b) Retomo facilmente a concentração.

4. Se tudo sai errado após trabalhar durante semanas em um projeto:

a) Preciso de muito tempo para me adaptar à situação.

b) Isso me incomoda um pouco e depois não penso mais.

7. Quando estou competindo e perco uma vez após a outra:

a) Consigo deixar de pensar rapidamente que perdi.

b) A ideia de que perdi não me sai da cabeça.

10. Se tivesse acabado de comprar um aparelho novo (por exemplo, um rádio) e por acidente, ele caísse no chão e não tivesse conserto:

a) Tentaria superar rapidamente.

b) Precisaria de muito tempo para superar.

13. Tenho que falar sobre algo importante e não consigo encontrar a pessoa:

a) Não consigo deixar de pensar nisso, ainda que esteja fazendo outra coisa.

b) Esqueço-me disso com facilidade até que volte a ver essa pessoa.

16. Quando compro muitas coisas em uma loja e, ao chegar a casa, percebo que paguei a mais, mas não posso recuperar o dinheiro:

a) Não consigo me concentrar em mais nada.

b) Esqueço o fato facilmente.

19. Quando me dizem que meu trabalho foi completamente insatisfatório:

a) Não deixo que isso me preocupe durante muito tempo.

b) Isso me deixa paralisado.

22. Estou em um engarrafamento e não chego a uma entrevista importante:

a) É difícil, para mim, começar a fazer outra coisa.

b) Rapidamente me esqueço disso e faço outra coisa.

25. Quando algo é muito importante para mim, mas não quer sair bem:

a) Desiludo-me pouco a pouco.

b) Simplesmente me esqueço e faço outra coisa.

28. Quando algo me deixa triste de verdade:

a) Custa-me fazer outra coisa.

b) É fácil que eu me distraia, fazendo outras coisas.

31. Quando várias coisas me saem mal no mesmo dia:

a) Normalmente, não sei o que fazer.

b) Simplesmente sigo adiante, como se nada tivesse acontecido.

34. Quando me empenho, ao máximo, para fazer um bom trabalho e tudo sai mal:

a) Não tenho muita dificuldade em começar outra coisa.

b) Custa-me muito fazer qualquer outra coisa. 
2. Quando tenho que terminar algo rapidamente:

a) Muitas vezes tenho que me obrigar a começar.

b) É fácil, para mim, começar e terminar.

5. Quando estou aborrecido porque não tenho nada de concreto para fazer:

a) Demoro a decidir o que deveria fazer.

b) Encontro rapidamente o que fazer.

8. Quando estou me preparando para abordar um problema difícil:

a) É difícil, para mim, enfrentar o problema.

b) Busco como resolvê-lo de uma forma mais ou menos agradável.

11. Quando devo resolver um problema difícil:

a) Normalmente, custa-me começar a resolvê-lo.

b) Minha mente tende a divagar em outras coisas, antes de começar a resolvê-lo.

14. Quando tenho que decidir o que deveria fazer ao ter, de forma inesperada, um tempo livre:

a) Levo muito tempo para decidir o que fazer.

b) Normalmente, consigo decidir o que fazer, sem ter que pensar muito.

\section{Quando tenho que fazer um trabalho em casa:}

a) Às vezes, demoro a iniciá-lo.

b) Normalmente, consigo fazê-lo imediatamente.

20. Quando tenho muitas coisas importantes para fazer e todas têm que estar prontas logo:

a) Frequentemente, não sei por onde começar.

b) É fácil, para mim, fazer um plano e cumpri-lo.

23. Quando existem duas coisas que realmente quero fazer, mas não posso fazer ambas:

a) Começo a fazer uma coisa e me esqueço da outra coisa que não pude fazer.

b) É difícil esquecer a outra coisa que não pude fazer.

26. Quando tenho que me ocupar com algo que é importante, mas também é desagradável:

a) Faço e me livro imediatamente.

b) Levo um tempo para fazê-lo por obrigação.

29. Quando me deparo com um grande projeto que deve ser feito:

a) Preciso dedicar muito tempo a pensar por onde começá-lo.

b) Não tenho dificuldade em começá-lo.

32. Quando tenho que fazer uma tarefa enfadonha:

a) Não tenho problemas para concluí-la.

b) Às vezes, não consigo começar a fazê-la.

35. Quando tenho a obrigação de fazer algo que me aborrece:

a) Faço-o logo e me livro.

b) Normalmente, leva um tempo até que comece a fazê-lo. 
Figure 5 - Orientation towards action in focused activity (OAA) versus volatility

3. Quando aprendo um jogo novo e interessante:

a) Canso-me logo do jogo e faço outra coisa.

b) Dedico ao jogo todo o tempo possível.

6. Quando estou trabalhando em algo importante para mim:

a) Gosto de fazer outras coisas também.

b) Dedico-me tão profundamente, que posso trabalhar nisso por muito tempo.

9. Quando vejo um filme muito bom:

a) Fico tão entretido que não penso em fazer mais nada.

b) Às vezes, quero fazer algo mais, enquanto estou vendo o filme.

12. Quando fico ocupado por muito tempo, fazendo algo interessante (por exemplo, ler um livro ou trabalhar em um projeto):

a) Às vezes, penso se realmente vale a pena o que estou fazendo.

b) Normalmente, estou tão concentrado no que estou fazendo que nunca paro para pensar se vale a pena.

15. Quando leio no jornal um artigo que me interessa:

a) Normalmente me interessa tanto que o leio inteiramente.

b) Frequentemente passo para outro artigo, antes de terminar o primeiro.

18. Quando estou de férias e passando-as bem:

a) Com pouco tempo, sinto vontade de fazer algo completamente diferente.

b) Não penso em fazer outra coisa até o final das minhas férias.

21. Quando um de meus amigos levanta um tema interessante de conversa:

a) Facilmente, transforma-se em uma grande conversa.

b) Logo perco o interesse e quero fazer algo diferente.

24. Quando estou ocupado trabalhando em um projeto interessante:

a) Preciso fazer intervalos frequentes e trabalhar em outros projetos.

b) Permaneço trabalhando no mesmo projeto durante muito tempo.

27. Quando estou tendo uma conversa interessante com alguém em uma festa:

a) Posso falar com essa pessoa todo o tempo.

b) Prefiro fazer outra coisa, depois de um tempo.

30. Quando acontece de eu ser muito melhor em um jogo do que os outros:

a) Normalmente, tenho vontade de fazer outra coisa.

b) É claro que quero continuar jogando.

33. Quando leio um artigo interessante:

a) Às vezes, quero deixar o artigo e fazer outra coisa.

b) Sento e leio o artigo durante muito tempo.

36. Quando desejo aprender algo novo e interessante:

a) Dedico-me a isso durante muito tempo.

b) Necessito de pequenas pausas para fazer outra coisa, durante um tempo.

\section{DISCUSSION}

In the Brazilian version, originally, the calculation of the scale scores followed the author's recommendations, which is to attribute one point to each of the answers whose alternative corresponds to the action, and then add up the points.
Hence, the scores on the three subscales should be calculated separately, due to the correlation with the distinct behaviors in each subscale. Hence, the sum of the action-oriented answers ranges between zero and 12. Below-average scores indicate a trend towards state orientation, while above-average scores indicate action orientation. ${ }^{16}$ 
The organization of the HAKEMP 90 considered the methodological recommendations for the translation and cross-cultural adaptation process. At bottom, the fundamental concepts that investigate the action or state orientation were maintained in all study phases. It is highlighted that the pilot test was fundamental to assess the appropriateness of the tool for the purpose of understanding and the mean time spent to apply it.

The translated version of the HAKEMP 90 preserved the capacity to identify essential elements which, among other equally important elements, should be present in students for the sake of a more efficient nursing care planning. As it gets closer to the research context, the investigation of projects is disseminated that adopt a more global and integrated perspective on motivation, cognition and volition, intention, attention and motivational factors. ${ }^{18}$ This arouses the discussion on the theoretical bases underlying active learning and helps students to advocate the control of their actions, cognitive integration, autonomy and the sense of self-determination ${ }^{19-20}$ to achieve targets in specific nursing situations.

In the research context, the adapted questionnaire was a valuable resource as a diagnostic tool of students' success, as it permits the early discovery of the risk for unsatisfactory performance in peculiar situations. After all, the factors that affect learning and decision making are seminal elements to plan and implement nursing care from the perspective of the Action Control Theory. ${ }^{21}$

\section{CONCLUSION}

The translation and cross-cultural adaptation of the HAKEMP 90 resulted in an instrument appropriate to the Portuguese language, with understanding and agreement among the items. The action control components that permeate the learning process in the Brazilian version of the HAKEMP 90 add relevant contribution to plan competent and humane nursing care. Thus, it provides for qualitative interventions in students' actions, as a tool that creates conditions to maintain the desire to learn, to make conscious and resolute decisions to accomplish the task and achieve the objectives.

\section{REFERENCES}

1. Kuhl J. A theory of self-regulation: action versus state orientation, self-discrimination, and some applications. Appl Psychol. 1992; 41(2):97-129.
2. Guirardello EB. Adaptação cultural e validação do instrumento Demandas de Atenção Dirigida. Rev Esc Enferm USP. 2005; 39(1):77-84.

3. Freire LGL. Auto regulação da aprendizagem. Ciênc Cognição [online]. 2009 [acesso 2009 Set 20]; 14(2):276-86. Disponível em: http:/ / pepsic.bvsalud. org/scielo.php?script=sci_arttext\&pid=S180658212009000200019\&lng=pt\&tlng=pt

4. Monteiro SC, Almeida LS, Vasconcelos RMCF. Abordagens à aprendizagem, autorregulação e motivação: convergência no desempenho acadêmico excelente. Rev Bras Orientac Prof [online]. 2012 [acesso $2015 \mathrm{Fev}$ 10]; 13(2):153-62. Disponível em: http// pepsic.bvsalud.org/scielo.php?script $=$ sci arttext\&pid=S1679-33902012000200003\&lng=pt\& nrm=iso

5. Hofer J, Holger B, Joscha K. Self-regulation and well-being: the influence of identity and motives. Europ J Personality. 2011; 25(3):211-24.

6. Andrés A, Abal F, Lozzia G, Gómez-Benito J, Aguerrí María E, Galibert MS et al. Adaptación del Cuestionario de Voluntad de Trabajo a una muestra de universitarios españoles. Anal Psicol [online] 2013 [acesso 2015 Fev 11]; 29(1):171-7. Disponível em: http://scielo.isciii.es/scielo.php?script=sci_ arttext\&pid=S0212-97282013000100020\&lng=es

7. Papantoniou G, Moraitou D, Katsadima E, Dinou M. Control de la acción y disposición a la esperanza: um studio de su incidência em la autorregulación del aprendizage. Electr J Resn Educ Psychol [online]. 2010 [acesso 2011 Ago]; 8(1):5-32. Disponível em: http://www.redalyc.org/pdf/2931/293121995002. pdf

8. Kuhl J, Kazén M, Quirin M. La teoría de la interacción de sistemas de la personalidad. Rev Mex Psicol [online]. 2014 [acesso 2015 Jan 12]; 31(2):90-9. Disponível em: www.researchgate. net/.../0046353cd60c79fbdb000000.pdf

9. Dieffendorf JM, Hall RJ, Lord RG, Strean ML. Action-state orientation: construct validity of a revised measure and its relationship to work-related variables. J Appl Psychol. 2000; 85(2):250-63.

10. Heckhausen H, Kuhl J. From wishes to action: the dead ends and short cuts on the long way to action. In: Frese M, Sabini J, organizadores. Goal-directed behavior: psychological theory and research on action. Hillsdale (NJ): Erlbaum; 1985. p. 134-60.

11. Castelo Branco EMS, Peixoto MAP, Alvim NAT. Escala do controle da ação para o diagnóstico de desempenho em estudantes de enfermagem. Rev Bras Enferm [online] 2013 [acesso 2014 Dez 3]; 66(6):942-8. Disponível em: http://www.scielo. br/scielo.php?script $=$ sci_arttext\&pid=S003471672013000600020\&lng=en

12. Kuhl J, Kazén M, Koole SL. Putting Self $\square$ Regulation Theory into practice: a user's manual. Appl Psychol. 2006; 55(3):408-18. 
13. Reichenheim ME, Moraes CL. Operacionalização de adaptação transcultural de instrumentos de aferição usados em epidemiologia. Rev Saúde Pública [online]. 2007 [acesso 2014 Dez 12]; 41(4):665-73. Disponível em: http://www.scielo. $\mathrm{br} /$ scielo.php? script $=$ sci_arttext\&pid $=$ S0034$89102007000400024 \& \operatorname{lng}=p t \& n r m=$ iso

14. Dorcas EB, Bombardie C, Guillemin F. Guidelines for the process of cross-cultural adaptation of self-report measures. Spine [online]. 2000 [acesso $2014 \mathrm{Dez}$ 3];25(24):3186-91. Disponível em: http://journals. lww.com/spinejournal/Abstract/2000/12150/ Guidelines_for_the_Process_of_Cross_Cultural.14. aspx

15. Viana, HB, Guirardello, EB, Madruga, VA. Tradução e adaptação cultural da Escala Askas: aging sexual knowledge and attitudes scale em idosos brasileiros. Texto Contexto Enferm. 2010 Abr-Jun; 19(2): 238-45.

16. Kuhl J. Action and state orientation: psychometric properties of the action control scales (ACS-90). In: Kuhl J, Beckmann J, organizadores. Volition and personality: action versus state orientation. Göttingen (DE): Hogrefe; 1994. p. 47-59.

17. Chatterjee M B, Baumann N, Osborne D. You are not alone: Relatedness reduces adverse effects of state orientation on well-being under stress. Pers Soc Psychol B. [online] 2013 [acesso 2015 Fev 11];39(4):43241. Disponível em: http://psp.sagepub.com/ content/early/2013/02/07/0146167213476895full

18. Koole SL, Kuhl J. Dealing with unwanted feelings: The role of affect regulation in volitional action control. In: Shah JY, Gardner WL, organizadores. Handbook of motivation science. New York (US): Gilford Press; 2008. p. 295-305.

19. Kuhl J, Beckmann J. Action control from cognition to behavior. $2^{\mathrm{a}}$ ed. Berlim (DE): Springer-Verlag; 2012.

20. Simão AMV, Frison LMB. Autorregulação da aprendizagem: abordagens teóricas e desafios para as práticas em contextos educativos. Cad Educ FaE/ PPGE/UFPel. [online] 2013 [acesso 2015 Jan 5]; 45: 2-20. Disponível em: http:// periodicos.ufpel.edu. br/ojs2/index.php/caduc/article/view/3814/3061

21. Castelo Branco EMS. O controle das ações do estudante de enfermagem na implementação dos cuidados preventivos para úlceras por pressão [tese]. Rio de Janeiro (RJ): Universidade Federal do Rio de Janeiro; 2007. 